\title{
A conventional Pitzer model for $\left\{\mathrm{Nd}^{3+}-\mathrm{H}^{+}-\mathrm{Na}^{+}-\mathrm{K}^{+}-\mathrm{Ca}^{2+}-\mathrm{Cl}^{-}-\mathrm{OH}^{-}\right\} \mathrm{aq}$ at $298 \mathrm{~K}, 0.1 \mathrm{MPa}$, and $2<\mathrm{pH}<13$
} C. S. OAKES
$1^{*}$, A. L. WARD
ICENHOWER
ICHUGUNOV

${ }^{1}$ PO Box 201, Trenton, KY, 42286 USA (*correspondence: oakescs@netscape.net)

${ }^{2}$ DOE, 4021 National Parks Hwy, Carlsbad, NM, 88220 USA ${ }^{3}$ Siena Natural Resources, 301 NW 63 ${ }^{\text {rd }}$ St., Oklahoma City, OK, 73118 USA

${ }^{4}$ Corning Inc., Sullivan Park, Corning NY 14831, USA

A Pitzer ion-interaction model is presented for the $\mathrm{Nd}^{3+}-\mathrm{H}^{+}-\mathrm{Na}^{+}-\mathrm{K}^{+}-\mathrm{Ca}^{2+}-\mathrm{Cl}^{-}-\mathrm{OH}^{-}$system at $298 \mathrm{~K}$ and 0.1 $\mathrm{MPa}$. This analog system is used for geochemical modeling of trivalent actinides [An(III)] in evaporite hosted nuclear waste repositories. In contrast to previous geochemical models for the An(III)-H-Na-K-Ca-Cl-OH system, the new model is both parsimonious and accurate.

Our model was fitted to isopiestic, emf and solubility data for the 'ternary' chloride salt systems. The model was then extended to $\mathrm{pHs}$ at which solid $\mathrm{Nd}(\mathrm{OH})_{3}, \mathrm{Nd}(\mathrm{OH})_{2} \mathrm{Cl}$ and a speculative double salt $\left(\mathrm{Nd}(\mathrm{OH})_{3} \cdot \mathrm{NdCl}_{3}\right)$ are stable. The two hydroxychloride salts join the stability fields of $\mathrm{NdCl}_{3} \cdot 6 \mathrm{H}_{2} \mathrm{O}$ and $\mathrm{Nd}(\mathrm{OH})_{3}$ to form a continuous model over $2<\mathrm{pH}<13$.

With addition of standard state free energy terms for crystalline (xt) and amorphous (am) $\mathrm{NdOH}_{3}(\mathrm{~s})$ and $\mathrm{NdOH}_{2}{ }^{+}$ and $\mathrm{Nd}(\mathrm{OH})_{3}{ }^{0}$ solute species, the model reproduces the full body of thermodynamic data over an ionic strength range from infinite dilution to the solubility limits of: $\mathrm{NaCl}, \mathrm{KCl}$, $\mathrm{CaCl}_{2} \bullet 6 \mathrm{H}_{2} \mathrm{O}, \mathrm{Nd}(\mathrm{OH})_{3}(\mathrm{~s})$, the hydroxychloride salts, and for mixtures containing up to 4.5 molal $\mathrm{HCl}(\mathrm{aq})$. No Pitzer parameters involving $\mathrm{NdOH}^{2+}, \mathrm{NdOH}_{2}{ }^{+}$and $\mathrm{Nd}(\mathrm{OH})_{3}{ }^{0}$ were necessary. The model adds 5 'binary' and 3 'ternary' Pitzer ion-interaction parameters to the set in Harvie et al. [1].

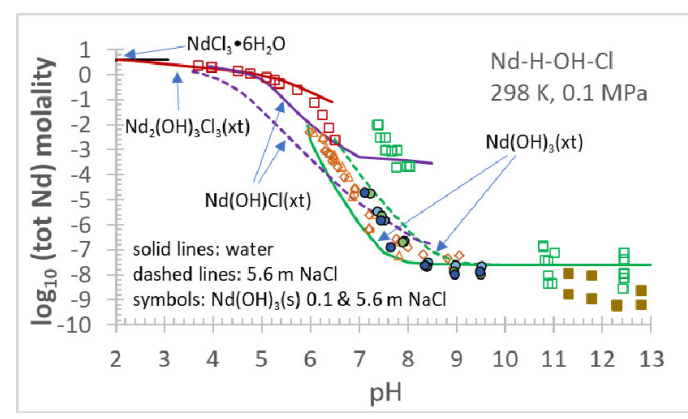

[1] Harvie et al. (1984) Geochim. Cosmochim. Acta 48, 723. 